PRACE NAUKOWE UNIWERSYTETU EKONOMICZNEGO WE WROCLAWIU

Wyzwania dla spójności Europy -

gospodarka, zrównoważony rozwój, konkurencyjność

\title{
Bernadeta Baran
}

Uniwersytet Ekonomiczny we Wrocławiu

e-mail: bernadeta.baran@ue.wroc.pl

\section{WYZWANIA UE \\ W ZAKRESIE ZRÓWNOWAŻONEGO ROZWOJU \\ W WYMIARZE EKOLOGICZNYM}

\section{EUROPEAN UNION'S CHALLENGES \\ FOR SUSTAINABLE GROWTH \\ IN THE ECOLOGICAL DIMENSION}

DOI: $10.15611 /$ pn.2017.466.02

JEL Classification: F64, Q51, I31

Streszczenie: W artykule wskazano najważniejsze wyzwania dla rozwoju zrównoważonego w wymiarze ekologicznym, przed jakimi staje obecnie Unia Europejska. Z lektury licznych raportów i wskaźników analizujących wpływ działalności gospodarczej na środowisko wynika, że jego skala jest bardzo duża. Istnieje więc potrzeba głębokiego uświadomienia tego problemu, ograniczeń wynikających z wydolności planety i znaczenia uwarunkowań środowiskowych dla jakości życia. Z przeprowadzonej analizy wynika, że ani postępy teoretyczne, ani wzrost świadomości ekologicznej czy nawet praktyczne ekoinnowacje nie zmieniły radykalnie sytuacji ekologicznej świata w ostatnich dekadach. Potwierdzeniem jest nie tylko aktualność problemów, ale wręcz ich multiplikacja.

Słowa kluczowe: środowisko, zrównoważony rozwój, polityka gospodarcza.

Summary: The article highlights the key challenges for sustainable development in the ecological dimension facing the European Union. Numerous reports and indicators analyzing the impact of economic activity show that its scale is large. There is therefore a need for deep awareness of the problem, the constraints of the capacity of the planet and the importance of environmental factors for the quality of life. The analysis shows that neither progress of theoretical knowledge nor the increase of environmental awareness or even practical eco-innovation has not radically changed the ecological situation in the world over the last years. This is confirmed not only by the topicality of the problems, but even their multiplication.

Keywords: environment, sustainable development, economic policy. 


\section{Wstęp}

Jak stwierdza Kołodko [2007], globalizacja to wielki triumf światowego kapitalizmu, ze wszystkimi jego konsekwencjami. Jedną z nich jest fakt, że nie potrafi on stawić czoła realnemu niebezpieczeństwu, jakim jest jego negatywny wpływ na ekosystem. Kapitalizm opiera się bowiem na racjonalności krótkoterminowej i efektywności mikroekonomicznej, co prowadzi do nadeksploatacji większości dóbr środowiskowych i narusza równowagę globalną [Szymański 2007].

Celem artykułu jest zaprezentowanie wyzwań dla rozwoju zrównoważonego w wymiarze ekologicznym, przed jakimi staje obecnie Unia Europejska. W badaniach zastosowano statystykę opisową w zakresie analizy wpływu aktywności gospodarczej na środowisko naturalne oraz skali przekształceń środowiska w Europie. Następnie zdefiniowano globalne megatrendy, które stanowią wyzwania dla zrównoważonego rozwoju w UE, oraz wskazano najważniejsze ograniczenia teoretyczne koncepcji zrównoważonego rozwoju. W artykule wykorzystano dane pochodzące $\mathrm{z}$ raportów opisujących zmiany w środowisku naturalnym oraz dokonano krytycznej analizy założeń koncepcji zrównoważonego rozwoju i wskazano możliwe kierunki zmian w sposobie oddziaływania gospodarek na środowisko.

\section{Wpływ aktywności gospodarczej na zmiany w środowisku naturalnym}

Współcześnie praktycznie wszystkie aktywności podejmowane przez człowieka wpływają na środowisko, jego zasoby oraz stabilność ekosystemów. Co prawda, rośnie świadomość wpływu człowieka na środowisko, jednak nieustanne dążenie do podwyższania dobrobytu, wzrost konsumpcji oraz związane z tym zapotrzebowanie na surowce i energię są i powinny być powodem niepokoju o ilość i jakość zasobów przyrody.

Sumaryczne negatywne oddziaływanie wywierane przez człowieka na środowisko jest w literaturze obrazowane wskaźnikiem „śladu ekologicznego” (EF, Ecological Footprint), nazywanym także ekologicznym odciskiem stopy. Jego wartość określa powierzchnię obszaru biologicznie produktywnego, jaki jest niezbędny do zaspokojenia potrzeb życiowych populacji ludzkiej z uwzględnieniem stylu życia. EF definiuje się jako obszar produktywnych ekosystemów lądów i mórz, niezbędnych do wyprodukowania zasobów wykorzystywanych przez ludzkość oraz do asymilacji odpadów przez nią wygenerowanych, przy czym obszary te są ściśle powiązane między sobą [Rees 1992; Rees, Wackernagel 1996].

Wartość EF jest uzależniona od rozwoju gospodarczego kraju, dlatego najniższe wskaźniki są charakterystyczne dla większości państw Afryki, a najwyższe m.in. dla USA, Kanady czy krajów UE. Według raportu Living Planet (2014) całkowita powierzchnia obszaru biologicznie produktywnego na Ziemi to ok. 11,9 miliardów 
globalnych hektarów (gha), tj. 1,8 gha na osobę, tymczasem w Ameryce Północnej wskaźnik ten wyniósł w 2014 r. 6,92 gha per capita, a w UE 4,53', co oznacza kilkukrotne przekroczenie ,potencjału biologicznego”. Skala wpływu człowieka na środowisko jest tak duża, że epokę zaczynającą się pod koniec XVIII w. zaczęto nazywać w literaturze antropocenem ${ }^{2}$ [Crutzen, Stoermer 2000]. Najważniejsze argumenty brzmią następująco: od początku rewolucji przemysłowej ludzie przekształcili ok. połowy powierzchni lądów i konsumują ponad połowę łatwo dostępnych zasobów słodkiej wody. Fabryki nawozów dostarczają do środowiska więcej azotu, niż znajduje się go w ziemskich ekosystemach, a skład ziemskiej atmosfery w wyniku zanieczyszczeń został istotnie i trwale zmieniony [The Economist 2011]. O niepokojącym, negatywnym wpływie działalności człowieka na środowisko mówią liczne raporty, m.in. FAO. Organizacja ta szacuje [FAO 2010], że wskaźniki wymierania gatunków są od 100 do 1000 razy szybsze niż w warunkach naturalnych: 60\% światowych ekosystemów uległo degradacji lub jest niewłaściwie wykorzystywanych; 75\% stad ryb jest nadmiernie eksploatowanych lub w znacznym stopniu wyczerpanych, a od $1990 \mathrm{r}$. na całym świecie utracono 75\% różnorodności genetycznej upraw rolnych. W licznych analizach podkreśla się, że zarówno poziomy krytyczne w skali globalnej, jak i regionalnej w niektórych obszarach zostały już przekroczone [Rockström i in. 2009].

\section{Przekształcenia środowiska w Europie}

Unia Europejska traktuje ochronę środowiska priorytetowo i podejmuje liczne działania zmierzające do poprawy ekosystemu. Z ostatniego raportu Europejskiej Agencji Środowiska [EAŚ 2015] wynika, że w wielu regionach kontynentu przedsięwzięcia te przyniosły realne skutki. W ujęciu europejskim postęp zauważono w obszarach: emisji gazów cieplarnianych (spadek o ok. 19\% w stosunku do 1990 r., przy jednoczesnym wzroście produkcji gospodarczej o ok. $45 \%{ }^{3}$ ), ilości energii wytwarzanej ze źródeł odnawialnych oraz efektywności wykorzystania energii, jakości wody, a także gospodarki odpadami. Niestety, w pozostałych obszarach dominują trendy negatywne lub co najmniej niejednoznaczne. Także w kontekście założonych celów długoterminowych (prognozy 20-letnie) żaden obszar nie wypada pozytywnie przewiduje się albo utrzymanie negatywnych tendencji, albo wręcz pogorszenie stanu. Do największych problemów środowiskowych w Europie należy zaliczyć: postępującą utratę różnorodności biologicznej, przekroczenie krytycznych poziomów

${ }^{1}$ Metodologia obliczeń [Lazarus i in. 2014].

2 Anthropo (gr. człowiek). Najmłodsza epoka geologiczna holocen, rozpoczęła się 11,7 tys. lat temu wraz z końcem epoki lodowcowej i wg popularyzatorów pojęcia antropocenu zakończyła się właśnie na początku wielkiej rewolucji przemysłowej, odkąd istotnie wzrosła skala wpływu człowieka na funkcjonowanie procesów przyrodniczych zachodzących w skali Ziemi.

${ }^{3}$ W tym samym raporcie podkreśla się jednocześnie, że za prawie połowę spadku emisji w latach 2008-2012 odpowiada kryzys i spowolnienie gospodarcze. 
substancji biogennych powodujących eutrofizację, wysoki poziom zanieczyszczenia powietrza i hałasu, znaczącą presję na ekosystemy lądowe (głównie w efekcie urbanizacji), postępującą utratę funkcji gleby czy degradację gruntów (tab. 1).

Tabela 1. Trendy i prognozy w wybranych obszarach środowiska w Europie

\begin{tabular}{|c|c|c|c|}
\hline & Obszary & $\begin{array}{l}\text { Trendy w ostatnich } \\
\text { 5-10 latach }\end{array}$ & $\begin{array}{l}\text { Prognozy na kolejne } \\
20 \text { lat } i \text { dalej }\end{array}$ \\
\hline 1 & 2 & 3 & 4 \\
\hline \multirow{7}{*}{ 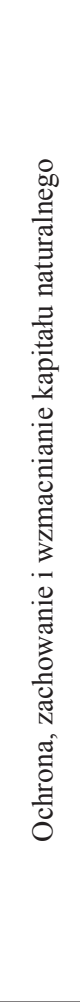 } & \begin{tabular}{|l} 
Różnorodność \\
biologiczna \\
w ekosystemach \\
lądowych \\
i słodkowodnych \\
\end{tabular} & $\begin{array}{l}\text { Duży udział gatunków chronionych } \\
\text { i siedlisk znajdujących się } \\
\text { w niewłaściwym stanie ochrony. }\end{array}$ & $\begin{array}{l}\text { Czynniki leżące u podstawy utraty } \\
\text { różnorodności biologicznej nie } \\
\text { zmieniają się w kierunku dla niej } \\
\text { korzystnym. }\end{array}$ \\
\hline & $\begin{array}{l}\text { Użytkowanie ziemi } \\
\text { i funkcje gleby }\end{array}$ & $\begin{array}{l}\text { Duża utrata funkcji gleby z powodu } \\
\text { rozwoju urbanizacji i degradacji } \\
\text { gruntów (np. w wyniku erozji gleb lub } \\
\text { intensyfikacji użytkowania ziemi). }\end{array}$ & $\begin{array}{l}\text { Zagospodarowanie i użytkowanie } \\
\text { ziemi nie będą zmieniać się } \\
\text { w sposób korzystny dla środowiska. }\end{array}$ \\
\hline & $\begin{array}{l}\text { Stan ekologiczny } \\
\text { jednolitych części } \\
\text { wód słodkich } \\
\end{array}$ & $\begin{array}{l}\text { Niejednoznaczne postępy: ponad } \\
\text { połowa rzek i jezior w gorzej niż } \\
\text { dobrym stanie ekologicznym. } \\
\end{array}$ & Spodziewany postęp. \\
\hline & \begin{tabular}{|l|} 
Jakość wody \\
i obciążenie \\
substancjami \\
biogennymi \\
\end{tabular} & $\begin{array}{l}\text { Poprawa jakości wody, ale obciążenie } \\
\text { substancjami biogennymi na wielu } \\
\text { obszarach pozostaje wysokie i wpływa } \\
\text { na stan wód. }\end{array}$ & $\begin{array}{l}\text { W regionach o intensywnej } \\
\text { produkcji rolnej rozproszone } \\
\text { zanieczyszczenie azotem nadal } \\
\text { będzie wysokie. }\end{array}$ \\
\hline & \begin{tabular}{|l|} 
Zanieczyszczenie \\
powietrza \\
i jego wpływ \\
na ekosystemy \\
\end{tabular} & $\begin{array}{l}\text { Mniejsza liczba przekroczeń } \\
\text { ładunków krytycznych zakwaszenia } \\
\text { i eutrofizacji. }\end{array}$ & $\begin{array}{l}\text { Na niektórych obszarach będą } \\
\text { utrzymywać się długoterminowe } \\
\text { problemy związane z eutrofizacją. }\end{array}$ \\
\hline & \begin{tabular}{|l|} 
Różnorodność \\
biologiczna \\
obszarów morskich \\
i przybrzeżnych \\
\end{tabular} & $\begin{array}{l}\text { Niewielka liczba gatunków znajdująca } \\
\text { się w dobrym stanie ochrony lub } \\
\text { środowiska. }\end{array}$ & $\begin{array}{l}\text { Presja na ekosystemy morskie } \\
\text { i skutki zmian klimatu mają } \\
\text { charakter trwały. }\end{array}$ \\
\hline & $\begin{array}{l}\text { Wpływ zmian } \\
\text { klimatu } \\
\text { na ekosystemy }\end{array}$ & $\begin{array}{l}\text { Zmiana cykli pór roku oraz } \\
\text { rozmieszczenia występowania wielu } \\
\text { gatunków. }\end{array}$ & $\begin{array}{l}\text { Prognozuje się coraz bardziej } \\
\text { dotkliwe zmiany klimatu i ich } \\
\text { skutki dla gatunków i ekosystemów. }\end{array}$ \\
\hline \multirow{3}{*}{ 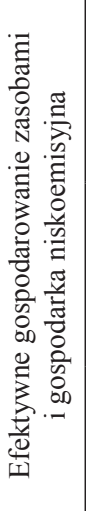 } & $\begin{array}{l}\text { Efektywne } \\
\text { zagospodarowanie } \\
\text { i wykorzystanie } \\
\text { zasobów } \\
\text { materialnych } \\
\end{array}$ & $\begin{array}{l}\text { Rozłączanie wykorzystania zasobów } \\
\text { i produkcji gospodarczej, chociaż } \\
\text { w pewnym stopniu przyczyniła się } \\
\text { do tego recesja gospodarcza. }\end{array}$ & $\begin{array}{l}\text { Europejskie systemy gospodarcze } \\
\text { są nadal zasobochłonne, a powrót } \\
\text { wzrostu gospodarczego może } \\
\text { odwrócić obserwowaną w ostatnich } \\
\text { latach poprawę sytuacji. }\end{array}$ \\
\hline & $\begin{array}{l}\text { Gospodarka } \\
\text { odpadami }\end{array}$ & $\begin{array}{l}\text { Spadek ilości odpadów } \\
\text { składowanych na wysypiskach, } \\
\text { dzięki zmniejszonemu wytwarzaniu } \\
\text { niektórych odpadów i zwiększeniu } \\
\text { skali recyklingu. }\end{array}$ & $\begin{array}{l}\text { Całkowita ilość wytwarzanych } \\
\text { odpadów będzie utrzymywać się na } \\
\text { wysokim poziomie. }\end{array}$ \\
\hline & \begin{tabular}{|l|} 
Emisje gazów \\
cieplarnianych \\
i łagodzenie zmian \\
klimatu
\end{tabular} & $\begin{array}{l}\text { Widoczny postęp (ograniczenie emisji } \\
\text { gazów cieplarnianych do } 19,2 \% \\
\text { poniżej poziomu z } 1990 \text { r.). }\end{array}$ & $\begin{array}{l}\text { Nie jest możliwe wkroczenie } \\
\text { UE na drogę do realizacji celu } \\
\text { dekarbonizacji do roku } 2050 \mathrm{r} \text {. }\end{array}$ \\
\hline
\end{tabular}


Tabela 1, cd.

\begin{tabular}{|c|c|c|c|}
\hline 1 & 2 & 3 & 4 \\
\hline \multirow{4}{*}{ 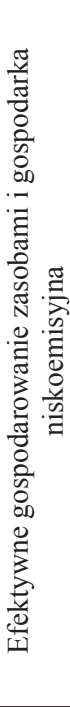 } & $\begin{array}{l}\text { Zużycie energii } \\
\text { i wykorzystanie } \\
\text { paliw kopalnych }\end{array}$ & $\begin{array}{l}\text { Wzrost energii wytwarzanej ze źródeł } \\
\text { odnawialnych i poprawa efektywności } \\
\text { wykorzystania energii. }\end{array}$ & $\begin{array}{l}\text { Paliwa kopalne będą dominować } \\
\text { w produkcji energii. Stworzenie } \\
\text { systemu energetycznego } \\
\text { przyjaznego dla środowiska } \\
\text { wymaga znacznych inwestycji. }\end{array}$ \\
\hline & $\begin{array}{l}\text { Zapotrzebowanie } \\
\text { na transport } \\
\text { i związany } \\
\text { z nim wpływ } \\
\text { na środowisko } \\
\end{array}$ & $\begin{array}{l}\text { Spadek zapotrzebowania } \\
\text { na usługi transportowe (ale wyłącznie } \\
\text { na skutek kryzysu finansowego } \\
\text { i gospodarczego); wpływ transportu } \\
\text { jest szkodliwy dla środowiska. }\end{array}$ & $\begin{array}{l}\text { Stworzenie zrównoważonego } \\
\text { systemu mobilności będzie } \\
\text { wymagać szybszego wprowadzenia } \\
\text { środków, co może okazać się trudno } \\
\text { wykonalne. }\end{array}$ \\
\hline & $\begin{array}{l}\text { Zanieczyszczenie } \\
\text { przemysłowe } \\
\text { powietrza, gleby } \\
\text { i wody }\end{array}$ & $\begin{array}{l}\text { Widoczne oddzielenie przemysłowych } \\
\text { emisji zanieczyszczeń od } \\
\text { produkcji przemysłowej w ujęciu } \\
\text { bezwzględnym. }\end{array}$ & $\begin{array}{l}\text { Poziom emisji przemysłowych } \\
\text { będzie nadal spadać, ale szkody } \\
\text { dla środowiska i zdrowia ludzi } \\
\text { pozostaną znaczące. }\end{array}$ \\
\hline & $\begin{array}{l}\text { Zużycie wody } \\
\text { i stres wody }\end{array}$ & $\begin{array}{l}\text { Zmniejszenie zużycia wody } \\
\text { w większości sektorów oraz } \\
\text { w większości regionów. Problemem } \\
\text { pozostaje jednak zużycie wody } \\
\text { do produkcji rolnej. }\end{array}$ & $\begin{array}{l}\text { Stres wodny pozostanie problemem } \\
\text { w niektórych regionach, a poprawa } \\
\text { efektywności może nie być } \\
\text { wystarczająca. }\end{array}$ \\
\hline \multirow{5}{*}{ 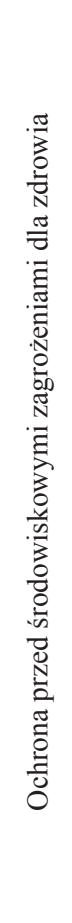 } & $\begin{array}{l}\text { Zanieczyszczenie } \\
\text { wody i powiązane } \\
\text { środowiskowe } \\
\text { czynniki ryzyka dla } \\
\text { zdrowia człowieka } \\
\end{array}$ & $\begin{array}{l}\text { Poprawa jakości wody pitnej i wody } \\
\text { w kąpieliskach. }\end{array}$ & $\begin{array}{l}\text { Problemem będą częstsze zdarzenia } \\
\text { ekstremalne (powodzie i susze) oraz } \\
\text { nowe zanieczyszczenia, takie jak } \\
\text { środki farmaceutyczne i produkty } \\
\text { higieny osobistej }\end{array}$ \\
\hline & $\begin{array}{l}\text { Zanieczyszczenie } \\
\text { powietrza } \\
\text { i powiązane } \\
\text { środowiskowe } \\
\text { czynniki ryzyka dla } \\
\text { zdrowia człowieka } \\
\end{array}$ & $\begin{array}{l}\text { Poprawa jakości powietrza. } \\
\text { Problemem pozostaje jednak drobny } \\
\text { pył zawieszony i ozon w warstwie } \\
\text { przyziemnej atmosfery. }\end{array}$ & $\begin{array}{l}\text { Przewiduje się poprawę jakości } \\
\text { powietrza, ale szkodliwe poziomy } \\
\text { zanieczyszczeń powietrza będą się } \\
\text { wciąż utrzymywać. }\end{array}$ \\
\hline & $\begin{array}{l}\text { Zagrożenie } \\
\text { hałasem }\end{array}$ & $\begin{array}{l}\text { Utrzymywanie się wysokiego } \\
\text { poziomu hałasu na stałym poziomie } \\
\text { (w wybranych aglomeracjach } \\
\text { miejskich). }\end{array}$ & $\begin{array}{l}\text { Brak danych, które umożliwiłyby } \\
\text { ocenę trendów długoterminowych. }\end{array}$ \\
\hline & $\begin{array}{l}\text { Systemy miejskie } \\
\text { i jakość życia }\end{array}$ & $\begin{array}{l}\text { Niska jakość powietrza, utrudniony } \\
\text { dostęp do terenów zielonych } \\
\text { i niekontrolowane rozrastanie się } \\
\text { obszarów miejskich. }\end{array}$ & $\begin{array}{l}\text { Przewiduje się wzrost presji } \\
\text { na zasoby i jakość środowiska } \\
\text { naturalnego na skutek wzrostu } \\
\text { populacji miejskiej. }\end{array}$ \\
\hline & $\begin{array}{l}\text { Chemikalia } \\
\text { i związane z nimi } \\
\text { środowiskowe } \\
\text { zagrożenia dla } \\
\text { zdrowia } \\
\text { człowieka }\end{array}$ & $\begin{array}{l}\text { Coraz większy problem stanowią } \\
\text { substancje zaburzające gospodarkę } \\
\text { hormonalną i nowo powstające } \\
\text { związki chemiczne. }\end{array}$ & $\begin{array}{l}\text { Chemikalia mogą oddziaływać } \\
\text { w sposób długofalowy, zwłaszcza } \\
\text { chemikalia trwałe i te wykazujące } \\
\text { zdolność do bioakumulacji. }\end{array}$ \\
\hline
\end{tabular}

Objaśnienia: kolory w 3 i 4 kolumnie oznaczają: kolor szary ciemny - dominację trendów negatywnych, kolor szary jasny - obraz niejednoznaczny, a brak koloru - dominację trendów pozytywnych.

Źródło: opracowanie na podstawie [EAŚ 2015]. 
$\mathrm{Z}$ raportu wynika, że pomimo poprawy sytuacji w wielu dziedzinach stan środowiska wciąż się pogarsza. Widoczna poprawa ma wymiar bardziej kosmetyczny i ograniczony do niewielkiej skali, nie wiąże się bowiem z zasadniczymi zmianami w podejściu człowieka do przyrody. Kapitał naturalny Europy jest w dalszym ciągu niszczony przez działalność społeczno-gospodarczą, taką jak rolnictwo, rybołówstwo, transport, przemysł, turystyka i niekontrolowane rozrastanie się miast. Należy więc uznać, że model rozwoju zrównoważonego w wymiarze ekologicznym jest bardzo daleki od realizacji.

\section{Globalne megatrendy jako wyzwania dla zrównoważonego rozwoju w UE}

Problemy ekologiczne nie znają granic między państwami, bo planeta stanowi system zamknięty, $\mathrm{z}$ określonymi cyklami naturalnymi i ograniczoną wydolnością. Zmian w środowisku w Europie nie można więc w pełni zrozumieć i nie można na nie wpływać w oderwaniu od globalnej dynamiki, i odwrotnie. $Z$ jednej strony, europejskie wzorce konsumpcji i produkcji przyczyniają się do presji na środowisko na kontynencie i w innych częściach świata. Kraje UE pozyskują zasoby i rozwijają produkcję w krajach rozwijających się i to tam pozostawiają największy „ślad ekologiczny"4 (co w globalnym, zamkniętym ekosystemie stanowi problem dla nich samych). Z drugiej natomiast, globalne megatrendy (dotyczące procesów demograficznych, wzrostu gospodarczego, wzorców produkcji i struktury handlu, postępu technologicznego, degradacji ekosystemów i zmian klimatu) kształtują wzorce konsumpcji w Europie i wpływają na europejskie środowisko i klimat. Szacuje się np., że do $2050 \mathrm{r}$. liczba ludności na świecie przekroczy 9 mld (obecnie $7 \mathrm{mld}$, a w $1950 \mathrm{r}$. było to niecałe $3 \mathrm{mld}$ ), a całkowity popyt na żywność, pasze i włókna wzrośnie o ok. $60 \%$ [FAO 2009]. Zaopatrzenie Europy w żywność, energię, wodę i surowce oraz dostęp do nich w perspektywie długoterminowej zależy więc nie tylko od poprawy efektywności wykorzystania tych zasobów i zapewnienia trwałości ekosystemów w Europie, ale także od globalnej dynamiki. Do istotnych zewnętrznych czynników wpływających na stan środowiska w UE należy zaliczyć:

- wzrost gospodarczy (tzn. jego prognozowane przyśpieszenie po trwającym od 2008 r. spowolnieniu), któremu będzie towarzyszyć intensyfikacja konsumpcji, wykorzystania zasobów i emisji zanieczyszczeń, w szczególności w Azji i Ameryce Łacińskiej;

${ }^{4}$ Ślad związany z użytkowaniem ziemi dla produktów zużywanych w UE w 56\% dotyczy obszarów poza terytorium UE. Na przykład szacunki emisji dwutlenku węgla związanych z konsumpcją w Europie wskazują, że europejski popyt napędza wytwarzanie emisji w innych częściach świata (więc pomimo spadku emisji gazów cieplarnianych w UE, następuje ich wzrost w ujęciu globalnym [EAŚ 2015]). 
- coraz bardziej wielobiegunowy świat, w którym wzrastająca liczba państw aktywnie uczestniczących w światowej strukturze politycznej i gospodarczej będzie wpływać na globalne współzależności i handel;

- postępujący proces urbanizacji: obecnie ok. połowa ludności na świecie mieszka na obszarach miejskich, a do 2050 r. liczba ta ma zwiększyć się do dwóch trzecich;

- coraz szybsze zmiany technologiczne (np. w obszarze biotechnologii, nanotechnologii), co z jednej strony stwarza możliwości zmniejszenia wpływu ludzi na środowisko i zwiększenia bezpieczeństwa zasobów, ale z drugiej jest związane z zagrożeniami i niepewnością.

Należy podkreślić, że skutki zmian w globalnej gospodarce dla środowiska i dla ludzi nie rozkładają się równomiernie. W większym stopniu narażone są na nie uboższe regiony i grupy społeczne, co będzie powodować dalszy wzrost nierówności społecznych, intensyfikować migracje i wpływać na kwestie bezpieczeństwa [EAŚ 2015].

Ważnym czynnikiem utrudniającym realizację koncepcji zrównoważonego rozwoju w ujęciu globalnym jest znaczne zróżnicowanie poziomu życia na świecie. Nowym środowiskowym wyzwaniom łatwiej jest sprostać krajom wysoko rozwiniętym, co wynika w dużej mierze z większej świadomości ekologicznej ich mieszkańców ${ }^{5}$. Większego znaczenia nabierają tu takie cechy produktów, jak: jakość, bezpieczeństwo zdrowotne, smak, tradycja czy kontekst społeczno-kulturowy procesu wytwarzania (podczas gdy w społeczeństwach o niższym poziomie dochodu podstawowym kryterium wyboru dóbr jest ilość i cena). Tzw. zielony konsumpcjonizm przejawiający się np. w ograniczaniu konsumpcji, wykorzystywaniu surowców odnawialnych bądź z odzysku czy kupowaniu wyrobów i technologii „przyjaznych środowisku" może przyczynić się do poprawy stanu środowiska, chociaż niejednokrotnie jest wykorzystywany do realizacji partykularnych celów przedsiębiorstwa (pozytywny wizerunek przedsiębiorstwa dbającego o środowisko staje się opłacalny, dlatego strategia firmy może się sprowadzać do zręcznych kampanii reklamowych lub „pewnych” zmian w systemie zarządzania, np. w celu uzyskania certyfikatów służących zbudowaniu pożądanego wizerunku). Z drugiej strony, także uczciwe przedsiębiorstwa muszą przynosić zyski, akumulować kapitał i rozrastać się, co nie pozostaje bez negatywnego wpływu na środowisko.

\footnotetext{
${ }^{5}$ Warto na przykład przytoczyć wyniki badań świadomości ekologicznej wśród Polaków. Na tle tak poważnych problemów ekologicznych w UE dla większości ankietowanych ochrona środowiska nie jest postrzegana jako obszar problematyczny (wskazało ją zaledwie 8\% uczestników badania). W odpowiedziach na pytania o najważniejsze zagrożenia dla środowiska w Polsce najczęściej wskazywano zanieczyszczenie powietrza, którego źródłem jest emisja z dużych obiektów energetycznego spalania oraz z transportu samochodowego. Dla ankietowanych głównym źródłem informacji o środowisku naturalnym jest telewizja (76\%) i Internet (30\%); 72\% uczestników badania nie poszukiwało żadnej informacji o środowisku i jego ochronie. Troska o środowisko naturalne u większości Polaków przegrywa z rachunkiem ekonomicznym - motorem oszczędzania energii czy wody jest bardziej troska o domowy budżet niż świadoma postawa ekologiczna [Raport TNS 2014].
} 


\section{Ograniczenia teoretyczne koncepcji zrównoważonego rozwoju}

Globalne zainteresowanie skutkami działalności gospodarczej człowieka dla środowiska ma swój początek na przełomie lat 60. i 70. XX w. [Meadows i in. 1972]. Od tego czasu często i licznie publikowano raporty zawierające listę zagrożeń i wyzwań dla przyszłego prawidłowego rozwoju ludzkości. W latach 80 . zdefiniowano pojęcie zrównoważonego rozwoju, który miał stać się sposobem poprawy sytuacji gospodarczej (wzrost PKB zapewniający odpowiednią ilość dóbr i usług), społecznej (zaspokajanie podstawowych potrzeb społecznych, zmniejszenie bezrobocia, podnoszenie jakości życia, itp.) i ekologicznej państw (poprawa stanu środowiska, zachowanie kapitału przyrodniczego, ochrona bioróżnorodności) [Hull 2011, s. 54]. W aspekcie ekologicznym koncepcja opiera się na założeniu, że istnieje rozwiązanie kompromisowe między dalszym rozwojem ekonomicznym a zachowaniem środowiska w jak najlepszym stanie ${ }^{6}$. Zrównoważony rozwój wyznaczył więc nowoczesny kierunek rozwoju gospodarek z poszanowaniem dóbr przyrody i stał się wezwaniem do zachowania rozwagi i umiaru zmierzających do pogodzenia kluczowych dla ludzkości obszarów: wzrostu gospodarczego z równomiernym podziałem korzyści.

W literaturze podkreśla się, że koncepcja zrównoważonego rozwoju postuluje całkowitą reformę dominującej teorii ekonomicznej [Rogall 2010, s. 83]. Należy jednak zauważyć, że nie narusza ona fundamentów paradygmatu neoliberalnego - teorii wzrostu gospodarczego [Matysiak, Struś 2015]. Teorie te zakładają, że rozwój jest procesem kierunkowym zmierzającym do ciągłego zwiększania dobrobytu materialnego społeczeństw, a głównym motywem działań gospodarczych są bodźce materialne. Ma on charakter endogeniczny, czyli jest zdeterminowany przez czynniki kontrolowane przez system społeczno-ekonomiczny (w efekcie wszelkie zewnętrzne zagrożenia rozwoju, takie jak np. zmiany klimatyczne, mogą być przezwyciężone w ramach systemu). Koncepcja zrównoważonego rozwoju kładzie właśnie nacisk na aktywne dopasowanie warunków ramowych za pomocą instrumentów polityczno-prawnych, aby w ten sposób zainicjować zrównoważoną przebudowę gospodarki, społeczeństwa i środowiska [Rogall 2010, s. 33]. Nie można zaprzeczyć, że stanowi ona odpowiedź na problemy końca XX w., ale jest też pojęciem bardzo szerokim, a rekomendacje dla praktyki nie wymagają od państw wysokorozwiniętych radykalnych zmian strukturalnych ${ }^{7}$. Platje [2006] podkreśla ponadto, że przy wdrażaniu idei

\footnotetext{
${ }^{6}$ Koncepcja zrównoważonego rozwoju nie jest precyzyjnie zdefiniowana, ulegając zmianie pod wpływem nowych wyobrażeń dotyczących m.in. uwzględniania celów ekonomicznych, socjalnych i ekonomicznych czy sposobów obserwacji zjawisk. Najbardziej popularna definicja określa tym mianem rozwój, który gwarantuje zaspokojenie potrzeb obecnych pokoleń, nie ograniczając możliwości zaspokojenia potrzeb przez przyszłe pokolenia [World Commission... 1987, s. 43].

7 Przykładem koncepcji radykalnej w znaczeniu ekonomicznym, która nie zyskała powszechnego uznania, był postulat wzrostu zerowego, który w założeniach autorów miał ustabilizować system gospodarczy do możliwości regeneracyjnych środowiska przyrodniczego [Zabłocki 2002]. W rezultacie to właśnie sformułowanie „rozwój zrównoważony” znalazło się w powszechnym użytku i stało się podstawą tworzenia licznych programów międzynarodowych i krajowych, szczególnie po Szczycie Ziemi w Rio w 1992 r.
} 
wzrostu zrównoważonego w UE wciąż przyjmuje się za priorytet wzrost gospodarczy, a kwestie środowiskowe i społeczne pozostają na drugim planie. Jeśli więc uznać ją nawet za zjawisko pozytywne, to stopień jej realizacji daleko odbiega od założeń: ani postępy teoretyczne, ani wzrost świadomości ekologicznej czy nawet praktyczne ekoinnowacje nie zmieniły radykalnie sytuacji ekologicznej świata w ostatnich dekadach. Potwierdzeniem jest nie tylko aktualność problemów i opinii zdefiniowanych przez pioniera koncepcji trwałego rozwoju - Browna [1982], ale wręcz multiplikacja problemów (źródłem wzrostu produkcji, zużycia zasobów naturalnych oraz konsumpcji są już nie tylko kraje wysoko rozwinięte, ale głównie nowe potęgi: Chiny i Indie, Brazylia, Indonezja czy Meksyk.

\section{Zakończenie}

Można spotkać opinie, że największym źródłem zagrożeń środowiskowych jest technologia produkcji, a rozwiązaniem problemów - wzrost produktywności czynników wytwórczych. Zwraca się też uwagę na konieczność wzmocnienia polityki ochrony środowiska czy podnoszenie poziomu świadomości ekologicznej. Lektura kolejnych raportów o stanie środowiska nie pozostawia jednak wątpliwości. W obliczu tak poważnych zmian destrukcyjnych środowiska nie wystarczy realizacja ambitnych założeń wynikających z koncepcji zrównoważonego rozwoju. Niezbędne są fundamentalne przemiany w systemach produkcji i konsumpcji, $\mathrm{tj}$. w instytucjach, praktykach, technologiach, politykach, oraz w stylu życiu i sposobie myślenia. Nadmierna eksploatacja środowiska nie wynika przede wszystkim ze stosowanej technologii, ale ma bezpośredni związek ze skalą konsumpcji i stylem życia (na co wpływ ma liczba ludności i poziom zamożności państw). Ekorozwój wymaga zmiany wartości, które co prawda przyczyniły się do rozwoju społeczno-gospodarczego, ale jednocześnie zachwiały równowagę $\mathrm{w}$ środowisku naturalnym. Najważniejszym motywem działalności przedsiębiorstwa był i wciąż pozostaje zysk (w tym celu firmy wykorzystują różne narzędzia marketingowe, nierzadko kreujące sztuczne potrzeby), a miejsca pracy powstające w miastach zachęcają do migracji i przyśpieszają procesy urbanizacji. Tymczasem miejskie życie większości ludzi na świecie wiąże się z uzależnieniem od systemu produkcji, ciągłą konsumpcją, brakiem czasu i refleksji nad skutkami decyzji konsumpcyjnych oraz często błędną hierarchią prawdziwych wartości w życiu. Słusznie stwierdza Zacher [2011], że innowacje techniczne, organizacyjne, instytucjonalne, polityczne, kulturowe, behawioralne to częściowe rozwiązania, które mogą złagodzić lub spowolnić kryzys ekologiczny. To, co konieczne, to zmiany w stylu życia i sposobie myślenia, zwiększenie narracji w kategoriach abstrakcyjnych czy filozoficznych (sprawiedliwość, globalny ład i etyka) i nadanie dyskursowi naukowemu i politycznemu charakteru multi- i interdyscyplinarnego. 


\section{Literatura}

Brown L.R., 1982, Jutro może być za późno, PWE, Warszawa.

Crutzen P.J., Stoermer E.F., 2000, The Anthropocene. Global Change Newsl.

EAŚ, 2015, Europejska Agencja Środowiska, Środowisko Europy 2015, stan i prognozy, Kopenhaga.

FAO, 2009, How to feed the world in 2050. Issue brief for the High-level Expert Forum, Rome, 12-13

October 2009, Food and Agriculture Organization of the United Nations.

FAO, 2010 za: Komunikat Komisji do Parlamentu Europejskiego, Rady, Europejskiego Komitetu Ekonomiczno-Społecznego i Komitetu Regionów Nasze ubezpieczenie na życie i nasz kapitał naturalny - unijna strategia ochrony różnorodności biologicznej na okres do 2020 r. Bruksela, 3.05.2011 $\operatorname{KOM}(2011) 244$ wersja ostateczna.

Hull Z., 2011, Wprowadzenie do filozofii zrównoważonego rozwoju, [w:] Tyburski W. (red.), Zasady kształtowania postaw sprzyjających wdrażaniu zrównoważonego rozwoju, Wydawnictwo UMK, Toruń

Kołodko G., 2007, Polska z globalizacja w tle. Instytucjonalne i polityczne aspekty rozwoju gospodarczego, Dom Organizatora, Toruń.

Lazarus E. i in., 2014, Working Guidebook to the National Footprint Accounts 2014, Global Footprint Network 2014.

Matysiak A., Struś M., 2015, Paradygmat rozwoju zrównoważonego, Studia Ekonomiczne, Zeszyty Naukowe UE w Katowicach nr 213, Katowice.

Meadows D. i in., 1972, Granice wzrostu, Raport dla Klubu Rzymskiego.

Platje J., 2006, Poziom dochodu a priorytety w rozwoju zrównoważony, [w:] Kozłowski S., Haładyj A. (red.), Rozwój zrównoważony na szczeblu krajowym, regionalnym i lokalnym - doświadczenia polskie i możliwości ich zastosowania na Ukrainie, Wydawnictwo Katolickiego Uniwersytetu Lubelskiego Jana Pawła II, Lublin.

Raport TNS, 2014, Badanie świadomości i zachowań ekologicznych mieszkańców Polski, Badanie trackingowe - pomiar: październik 2014, Raport TNS Polska dla Ministerstwa Środowiska.

Rees W., 1992, Ecological footprints and appropriated carrying capacity: what urban economics leaves out?, Environment and Urbanisation, vol. 4, no 2.

Rees W., Wackernagel M., 1996, Our Ecological Footprint: Reducing Human Impact on the Earth, New Society Publishers, Vancouver.

Rockström J. i in. (2009), A safe operating space for humanity, Nature 461(7263).

Rogall H., 2010, Ekonomia zrównoważonego rozwoju. Teoria i praktyka, thum. J. Gilewicz, Wydawnictwo Zysk i S-ka, Poznań.

Szymański W., 2007, Czy globalizacja musi być racjonalna?, Wydawnictwo SGH, Warszawa.

The Economist, Welcome to the Anthropocene, May 26th 2011.

World Commission on Environment and Development, 1987, Our Common Future, New York.

WWF International, 2014, Living Planet, Report 2014, Species and space, people and places.

Zabłocki G., 2002, Rozwój zrównoważony - idee, efekty, kontrowersje (perspektywa socjologiczna), Wydawnictwo UMK, Torun.

Zacher L.W., 2011, Dyskurs ekologiczny - między teoria a praktyka, [w:] Poskrobko B. ( red.), Uwarunkowania rozwoju zrównoważonej gospodarki opartej na wiedzy, Białystok. 